\title{
PROSPECT STUDY OF THE CELLARS IN SĂLACEA, BIHOR COUNTY, ROMANIA
}

\author{
Tudor CACIORA* \\ Student, University of Oradea, Faculty of Geography, Tourism and Sport \\ $1^{\text {st }}$ University Street, Oradea, 410 087, Romania, e-mail: tudor.caciora@yahoo.com \\ Grigore Vasile HERMAN \\ University of Oradea, Department of Geography, Tourism and Territorial Planning, 1 University St., 410 087, Oradea, \\ Romania, e-mail: grigoreherman@yahoo.com \\ Kéri GÁSPÁR \\ President of the association “Agroturismul Văii Ierului”, Tarcea Common, Galoșpetreu Village, nr. 517, \\ Romania, e-mail: kerigaspar@freemail.hu
}

Citation: Caciora, T., Herman, G. V., Kéri, G. (2019). Prospect Study of the Cellars in Sălacea, Bihor County, Romania. Analele Universităţii din Oradea, Seria Geografie, 29(2), 40-45. https://doi.org/10.30892/auog.292104-812

\begin{abstract}
Globalisation is considered to be a defining phenomenon for the present society having a decisive impact in the outlining and evolution of local identiy elements. The main purpose of the study is to localise, record and analyse the cellars found in Sălacea in order to preserve, promote and profit from their use in tourism. The methods used were the study of the speciality literature and onsite visits. Therefore, a series of specific software programs were used, the results having created a digital data base which may be considered as an informational support for other scientific procedures, including the identification of a series of opportunities for local development.
\end{abstract}

Key words: local identity, cellars, tourism, local development

$$
* \quad * \quad * \quad * \quad * *
$$

\section{INTRODUCTION}

Sălacea is the residence village of the commune bearing the same name, located in the Northern part of Bihor County, Romania. The village is located in the area which connects Câmpia Ier's Lower Meadow and Salacea's Hills, a diverse natural habitat which gives the area complex economic characteristic, based on the culture of plants, commerce, fishing and animal breeding.

The favourable topoclimate conditions of this habitat (Șerban, 2010; Sabău, 1997) are well highlighted through the multi-secular occupations of the local population (defining Sălacea, as well as the entire Ier Valley) connected to the cultivation of grapes and wine production. As evidence for this long and old oenological tradition are the great number of cellars dug within the 
hills which border the village in its Southern part. The architectural elements which compose the structure of the cellars, physically transfer a series of cultural and ethnographic values as well as specific features of the location as well as of the local community.

The identity and specificity features given by the cellars in Sălacea, are brought forward by their large number (approximately 956; according to Keri and Kantor, 2009), their layout in lines which make up real streets of cellars independent from the households, as well by their distinct architecture (Lincu et al., 2018). All these features give them a kind originality and uniqueness differentiating them from other such constructions (cellars) in Ier Valley.

Originally the cellars were dug in order to preserve the wine in favourable environment for a longer period of time as well as storing the tools used for the oenological procedures. Later on, as the vine surfaces were reduced, the cellars were used as storing places for fruit and vegetables as well as for the tools used to work the land.

For the local people, the cellars represented for a long period of time an integral part of their social and cultural life as well as a way of showing off their wealth (Iren, 2003). Therefore, the number and size of the cellars owned by a family were in direct proportion to its wealth (Lincu et al., 2018).

Considering therefore all of the above, it is safe to say that the cellars represent valuable testimonials with historical values supplying essential pieces along with other categories of anthropic resources (Ilieș et al., 2010; Ilieș et al., 2016; Staşac and Herman, 2010; Tătar and Herman, 2013), of information regarding the past of Sălacea, traditions, culture and habits, contributing massively to the creation of a spatial identity of the place (Herman and Wendt, 2011; Herman, 2012; Ilieș et al., 2017). Being the beneficiary of a series of essential attributes (age, uniqueness, innovation, functionality, representation, etc.) the cellars are latent touristic resources with a great potential in the genesis evolution and dynamics of the local tourism (Herman et al., 2017; Ilie et al., 2017; Herman et al., 2018b).

The analysis of the speciality literature concerning the studied habitat it reveals the existence of several studies which deal with the particularities of the natural (Ilieș et al., 2017; Herman et al., 2016; Czirjak, 2014; Ardelean and Karacsonyi, 2002; Szilagyi et al., 2012) and socio-cultural environment of Sălacea (Ilieș et al., 2014; Iren, 2003; Indrie et al., 2019; Keri and Kantor, 2009; Keri, 2015).

Wine cellars do not represent a new study subject, the cellars being found among the research concerns of several authors (Linc et al., 2017; Dincă et al., 2012; Fernandes and Cruz, 2016; Martins et al., 2017; Lincu et al., 2018).

Despite the fact, the role and importance of the cellars for the rural society are still unknown to the large public, not mentioning their historic role and importance in outlining the identity specific to the place as a basic support in affirming and developing tourism as a durable alternative for a responsible capitalisation of the territory (Herman and Gherman, 2016; Herman and Benchiş, 2017; Herman et al., 2018a).

Based on this background, the main purpose of the present study is to carry out an inventory of the cellars independent of the households in Sălacea village, in order to create a data base (photos, audio-video materials, drawings, graphic materials and cartographic projections) which should be used as informational support for other scientific procedures, including here the possibility to identify opportunities for local development.

\section{RESEARCH METHOD}

The present study brings forward the results of the researches comprised by the speciality literature and carried out on site. Four on site research expeditions were carried out between the $15^{\text {th }}$ of April and the $20^{\text {th }}$ of April 2019 in order to identify and map all the cellars. The mapping was carried out using the spatial coordinates' identification method for each cellar, i.e. latitude and longitude, using the Magellan eXplorist 310. The analysis of the particularities of the territory and the mapping supposed the use of the following software programs: 3D Map Generator and ArcMap 10.6. The cartographic materials, as well as the photographic data base resulted after the onsite researches were processed in Adobe Photoshop CC 2015.5 and CorelDRAW X7. 


\section{RESULTS AND DISCUSSIONS}

Sălacea is also called "the village of 1000 cellars", an allusion to the high number of such constructions being present on site. The number of cellars in Sălacea is a rather controversial subject, as from the discussions had on site most of the locals claim that their number exceeds 900 , while others declare that "Sălacea comprises more cellars than houses". A rather similar situation results therefore from the analysis of the speciality literature, where a number of 956 cellars is mentioned (Keri and Kantor, 2009).

The scope of the researches in the field was to highlight the exact location of each and every cellar, create an inventory regarding their number and their association in agglomerations and "alleys", streets with cellars as well as their access (rods, pedestrians) in order to capitalise them inthrough tourism.

Therefore, after having carried out the researches in the field, a number of 594 independent cellars were identified, all being dug within the slopes of the hills on the Southern side of the locality (figure 1, table 1).

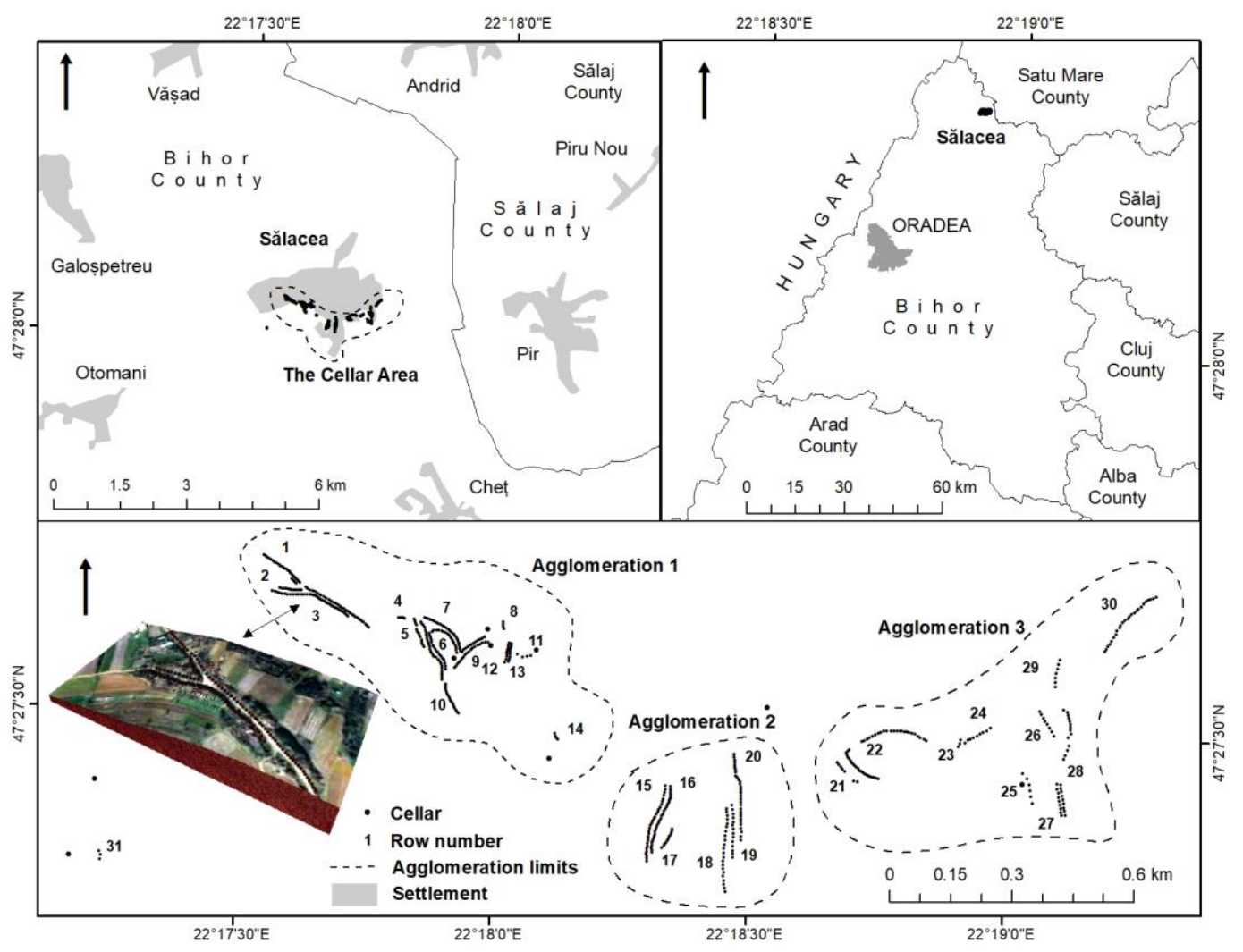

Figure 1. The spatial repartition of cellars within Sălacea

It has to be mentioned that some cellars were omitted during the inventory, and we are talking here about those cellars located on private land, inside the villagers' gardens, where the access was either restricted or in some cases forbidden. Therefore, it is safe to say that their touristic potential (i.e. of the cellars within the households) is very limited.

The general analysis of the cellars in Sălacea reveals the existence of three main agglomerations. The largest agglomeration (considering the number of cellars comprised) is 
located in the South-Western part of the village, comprising 14 rows of cellars, respectively 295 cellars (i.e. 21.1 units / row). The second largest agglomeration is located in the Southern part of the village and comprises 6 rows, respectively 147 units (24.5 units / row). The South-Eastern agglomeration Sălacea has the largest territorial expansion, comprises 10 rows of 146 units, the average being 14.6 cellars / row. Next to the three agglomerations, another 6 isolated cellars were identified, located outside the territory of the village (table 1).

The analysis of the rows considering the number of cellars reveals the predominance of rows 1 (56 units), 22 (48 units), 3 (39 units), while at the opposite pole there are rows 23 and 31 (with 3 units each), 8, 11 and 14 (with 4 units each) and 25 (6 units) (table 1).

Table 1. Centralising table regarding the cellars in Sălacea Village, Bihor County

\begin{tabular}{|c|c|c|c|c|c|}
\hline Agglomerations & $\begin{array}{l}\text { Number of } \\
\text { rows }\end{array}$ & Rows code & $\begin{array}{l}\text { Number of } \\
\text { cellars }\end{array}$ & Road structure & Road category \\
\hline \multirow{13}{*}{ Agglomeration 1} & \multirow{13}{*}{13} & 1 & 56 & paved & II \\
\hline & & 2 & 16 & paved & II \\
\hline & & 3 & 39 & paved & II \\
\hline & & 4 & 17 & ground & II \\
\hline & & 5 & 30 & paved & II \\
\hline & & 6 & 34 & paved & II \\
\hline & & 7 & 38 & paved & II \\
\hline & & 8 & 4 & paved & II \\
\hline & & 9 & 18 & paved & II \\
\hline & & 10 & 17 & paved & II \\
\hline & & 11 & 4 & paved & III \\
\hline & & 12 & 9 & ground & III \\
\hline & & 13 & 9 & ground & III \\
\hline \multirow{7}{*}{ Agglomeration 2} & \multirow{7}{*}{7} & 14 & 4 & asphalted & $\mathrm{I}$ \\
\hline & & 15 & 30 & asphalted & I \\
\hline & & 16 & 32 & asphalted & $\mathrm{I}$ \\
\hline & & 17 & 11 & paved & II \\
\hline & & 18 & 22 & paved & II \\
\hline & & 19 & 14 & ground & IV \\
\hline & & 20 & 32 & ground & IV \\
\hline \multirow{10}{*}{ Agglomeration 3} & \multirow{10}{*}{10} & 21 & 7 & ground & IV \\
\hline & & 22 & 48 & paved & III \\
\hline & & 23 & 3 & ground & IV \\
\hline & & 24 & 9 & ground & IV \\
\hline & & 25 & 6 & ground & IV \\
\hline & & 26 & 8 & asphalted & $\mathrm{I}$ \\
\hline & & 27 & 9 & paved & II \\
\hline & & 28 & 23 & paved & II \\
\hline & & 29 & 7 & ground & IV \\
\hline & & 30 & 25 & ground & IV \\
\hline Isolated & 1 & 31 & 3 & ground & IV \\
\hline
\end{tabular}

Access represent a fundamental criterion for the capitalisation of these elements through tourism. Therefore, the streets which include cellars are favoured by their positioning in the immediate proximity of the main street alignment, being connected either direct or through a series of connecting alleys. If there is an easy pedestrian or bike access, the access by car is difficult due to the geographical layout and the impracticable roads.

The analysis of the rows of cellars concerning the access roads' surface reveals the existence of three cases: asphalted streets (4 rows of cellars), paved streets (15 rows) and ground streets (12 rows) (table 1, figures 2-4). 


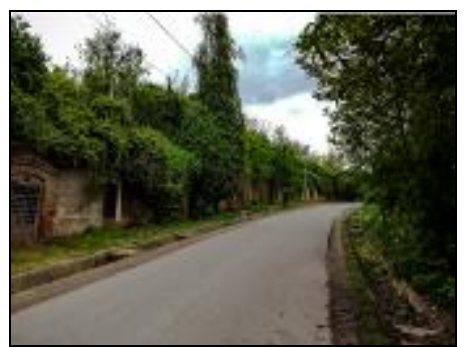

Figure 2. Asphalted street

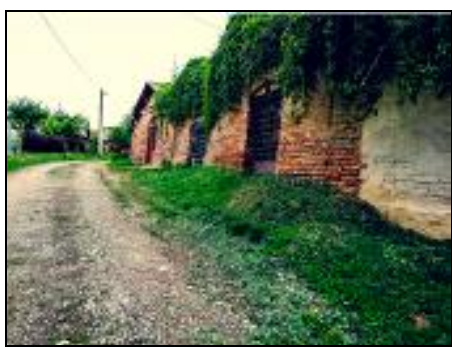

Figure 3. Paved street

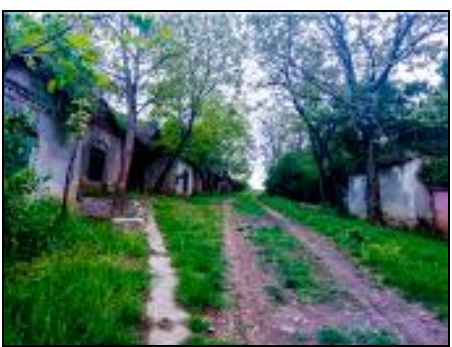

Figure 4. Ground street

After the field research and analysis, the rows of cellars were divided into four categories considering the practicability degree of the access road for vehicles especially cars. The $1^{\text {st }}$ category includes 4 rows which are located on asphalted streets with easy access, $2^{\text {nd }}$ category is the largest category as it includes 14 units and it is individualised by paved roads with a rather good access independent on the season or the weather conditions. The roads which comprise the four rows of cellars $(4,5,6,22)$ depend on the weather conditions and they belong to the $3^{\text {rd }}$ category. A low quality of the roads is recorded for the $2^{\text {nd }}$ and $3^{\text {rd }}$ agglomerations $\left(4^{\text {th }}\right.$ category -9 rows), being therefore represented by narrow pathways with the rows of the cellars only on one side, usually inaccessible for vehicle all year round (table 1).

\section{CONCLUSIONS}

The cellars in Sălacea village have a great historical and architectural value, their structure comprising important specific local elements. The appearance and development as well of the three agglomerations of cellars, spread on 31 rows, 594 cellars represent a reflex, an imposed condition by the natural environment on one hand and by the socio-economical context on the other. Their economic and symbolic value, doubled by the relatively easy access and their proximity to Oradea may considered as strengths in the development of the local economy based on the capitalisation of such local identity elements. Independent cellars have a great impact in outlining the identity of Sălacea Village, on Ier Valley, Bihor County, Romania. These are vivid testimonials of a universe lost in the blur of time, a world where the habits and traditions were kept to the book and where under the more and more acute pressure of globalisation risks of becoming one with the past.

\section{REFERENCES}

Ardelean, G., Karacsonyi, C. (2002). Flora și fauna Văii Ierului (înainte și după asanare) [Flora and fauna of the Ier Valley (before and after the restoration)], Bion Publishing, Satu Mare, Romania (in Romanian).

Czirjak, R. L. (2014). Flora și vegetaţia Văii Ierului [The flora and vegetation of the Ier Valley], Doctoral Dissertation, University of Oradea, Oradea, Romania, (in Romanian).

Dincă, I., Herman, G. V., Sztankovics, G., (2012). Descoperire prin ecoturism și prin turism rural în Comuna Cetariu [Discovering through ecotourism and rural tourism in Cetariu Commune], University of Oradea publishing, Oradea, Romania, (in Romanian).

Fernandes, T., Cruz, M. (2016). Dimensions and outcomes of experience quality in tourism: The case of Port wine cellars. Journal of Retailing and Consumer Services, 31, 371-379.

Herman G. V, \& Wendt J. (2011). Development and promotion of tourism, an extra chance in maintaining and asserting the identity and specificity of Oas Land. GeoJournal of Tourism and Geosites, 7(1), 87-94.

Herman G. V. (2012). The Role and the Importance of Historical Monuments in the Diversification of Touristic Services in Oaş Land. Forum Geografic, Studii și cercetări de geografie și protecția mediului, 11(2), 229-234.

Herman G. V., \& Gherman V. (2016). Identification, quantification and analysis of the ethnographic potential of folk songs specific to Bihor, Romania. Analele Universităţii din Oradea, Seria Geografie, 26(2), 261-267.

Herman G. V., Deac A. L., Ciobotaru A.-M., Andronache I. C., Loghin V., \& Ilie A. M. (2017). The role of tourism in local economy development. Bihor County Case Study. Urbanism Architecture Constructions, 8(3), 265-274.

Herman, G. V., \& Benchiș, L. B. (2017). Fairs, forms of expression of the local identity. Case study: Beiuș fair, Bihor County, 
Romania. Analele Universităţii din Oradea, Seria Geografie, 27(1), 108-113.

Herman, G. V., Ilieș, D. C., Baias, Ș., Măduța, M. F., Ilieș, A., Wendt, J., \& Josan, I. (2016). The tourist map, scientific tool that supports the exploration of protected areas, Bihor County, Romania. GeoSport for Society, 4(1): 24-32.

Herman, G. V., Tătar, C. F., \& Puşcaş, B. D. (2018a). Assessing the importance of the Jewish urban cultural heritage in Oradea, Bihor County, Romania. Forum Geografic 17(2), 151-158.

Herman, G. V., Peptenatu, D., Grama, V., \& Pintilii, R. D. (2018b). Tourism and Local Development. Study Case: Băile Felix-Băile 1 Mai Tourism System, Bihor County, Romania. Analele Universitatii din Oradea. Seria Geografie, 28(1), 131-137.

Ilie A. M., Herman G. V., Ciobotaru A. M., Grecu A., Radu R. A., Visan M. C., \& Giurgia M. (2017), The role of tourism in structural dynamics of the economic profile of Sighisoara city. Urbanism. Arhitectura. Constructii [Urbanism Architecture Constructions], 8(4), 377-386.

Ilieş A. (coord.), Baias Ş., Baias Iuliana, Blaga L., Buhaş S., Chiriac A., Ciocan J., Dăncuş M., Deac Anca, Dragoş P., Dumitrescu Ghe., Gaceu O., Godea I., Gozner Maria, Grama V., Herman G., Hodor N., Hurley P., Ilieş A., Ilieş Dorina, Ilieş Gabriela, Ilieş M., Josan Ioana, Leşe G., Măduţa F., Mojolic Diana, Morar C., Olaru M., Staşac M., Stupariu M., Sturza Amalia, Ştefănescu B., Tătar Corina, Vârnav R., Vlaicu M., Wendt J. (2014). Crişana - Maramureş, Atlas Geografic al patrimoniului turistic, Editura Universităţii din Oradea, ISBN 978-606-10-12-96-5, Oradea.

Ilieş A., Ilieş D. C., Josan I., Wendt J., Herman G. V., \& Grama V. (2010). The identification, evaluation, quantification and capitalization through tourism of the authentic resources from Crisana-Maramures with the purpose of elaborating a strategy of cross-border integrated sustainable development. Methodological approach. Analele Universitatii din Oradea, Seria Geografie, 20(1), 127-140.

Ilieș A., Wendt J. A., Ilieș D. C., Herman G. V., Ilieș M., \& Deac A. L. (2016), The patrimony of wooden churches, built between 1531 and 2015, in the Land of Maramureș, Romania. Journals of Maps 12(Supp1), 597-602.

Ilieș, A., Ilieș, D. C., Tătar, C., \& Ilieș, M. (2017). Geography of tourism in Romania, In: Widawski K., Wyrzykowski J. (eds) The Geography of Tourism of Central and Eastern European Countries, Springer Edition, ISBN 978-3-319-42203-9.

Ilieș, A., Ilieș, D., Josan, I., Grama, V., \& Gozner, M. (2008). Romanian Rural Tourism between authentic/traditional and modern/contemporary. The case of Crișana and Maramures area. GeoJournal of Tourism and Geosites, 2(2), 140-148.

Indrie, L., Oana, D., Ilieș, M., Ilieș, D. C., Lincu, A., Ilieș, A., Baias, Ș., Herman, G., Oneț, A., Costea, M., Marcu, F., Burtă, L.., \& Oana, I. (2019). Indoor air quality of museums and conservation of textiles art works. Case study: Salacea Museum House, Romania. Industria Textilă, 70(1), 88-93.

Iren, G. (2003). Szalacs Kismonografia [The short monograph of Salacea], Partium Fuzatek, 26 (in Hungarian).

Keri, G. (2015). Impletituri vegetale din Valea Ierului [Vegetable braids from Ier Valley], Martor Publishing, București, Romania, (in Romanian).

Kéri, G., \& Kántor, A. (2009). Az érmelleki szölőmüvelés épitészeti és tárgyi emlékeinek védelme [Protecting the architectural and material memories of vine growing in the coins], Hajdúböszörmény, ISBN 978-963-86420-5-9 (in Hungarian).

Linc, R., Dincă, I., Tătar, C., Stașac, M., Nistor, S., \& Bucur, L. (2017). The household independent cellars of Oradea Hills, Romania: a change to continuity through the human and enviromental capital. Analele Universitatii din Oradea. Seria Geografie, 27(2), 141-152.

Lincu, A., Ilieș, M., Ilieș, D. C., Herman, G. V., Baias, Ș., Gozner, M., Costea, M., \& Mihincău, D. (2018). Conservating the traditional cellars of Sălacea, Bihor County, Romania. GeoJournal of Tourism and Geosites, 23(3), 748-758.

Martins, J., Gonçalves, R., Branco, F., Barbosa, L., Melo, M., \& Bessa, M. (2017). A multisensory virtual experience model for thematic tourism: A Port wine tourism application proposal. Journal of Destination Marketing \& Management, 6(2), 103-109.

Sabău, N. C. (1997). Impactul lucrărilor hidroameliorative asupra solurilor din perimetru Valea Ierului [Impact of the hydroameliorative works on the soils in the Valea Ierului perimeter], Editura Universității din Oradea (in Romanian).

Staşac M., \& Herman G. V. (2010). Ethnographic values in the traditional village of Zarand Land. GeoJournal of Tourism and Geosites, 6(2), 140-150.

Szilaghyi, F., Czegledi, J., \& Molnar, Z. (2012). Szülöföldünk: Bihari Érmellék [Our homeland: The Ier Valley from Bihor], DTP STUDIO, Érmihályfalva, Romania (in Hungarian).

Șerban, E. (2010). Hazarde climatice generate de precipitații în Câmpia de Vest situată la nord de Mureș [Climatic hazards generated by precipitation in the Western Plain north of Mureş], Editura Universității din Oradea (in Romanian).

Tătar C. F., \& Herman G.V. (2013), Identity Encounters. Host-Guest Interractions in the Land of Moţi. GeoJournal of Tourism and Geosites, 11(1), 66-74.

Submitted:

May 15, 2019
Revised:

June 20, 2019
Accepted and published online July 12, 2019 